

\title{
pommalina
}

\section{Species identification from genetic material with cytochrome $\mathbf{b}$}

$\begin{array}{ll}\text { Autor(es): } & \begin{array}{l}\text { Costa, H. Afonso; Balsa, F.; Bento, A. M.; Serra, A.; Lopes, V.; Carvalho, } \\ \text { M.; Andrade, L.; Batista, L.; Oliveira, C.; Corte-Real, F.; Anjos, M. J. }\end{array} \\ \text { Publicado por: } & \begin{array}{l}\text { Imprensa da Universidade de Coimbra; International Academy of Legal } \\ \text { Medicine }\end{array} \\ \text { URL } & \text { URI:http://hdl.handle.net/10316.2/31754 } \\ \text { persistente: } & \text { DOI:http://dx.doi.org/10.14195/978-989-26-0173-1_16 } \\ \text { DOI: } & \text { 26-Apr-2023 00:36:04 } \\ \text { Accessed : } & \end{array}$

A navegação consulta e descarregamento dos títulos inseridos nas Bibliotecas Digitais UC Digitalis, UC Pombalina e UC Impactum, pressupõem a aceitação plena e sem reservas dos Termos e Condições de Uso destas Bibliotecas Digitais, disponíveis em https://digitalis.uc.pt/pt-pt/termos.

Conforme exposto nos referidos Termos e Condições de Uso, o descarregamento de títulos de acesso restrito requer uma licença válida de autorização devendo o utilizador aceder ao(s) documento(s) a partir de um endereço de IP da instituição detentora da supramencionada licença.

Ao utilizador é apenas permitido o descarregamento para uso pessoal, pelo que o emprego do(s) título(s) descarregado(s) para outro fim, designadamente comercial, carece de autorização do respetivo autor ou editor da obra.

Na medida em que todas as obras da UC Digitalis se encontram protegidas pelo Código do Direito de Autor e Direitos Conexos e demais legislação aplicável, toda a cópia, parcial ou total, deste documento, nos casos em que é legalmente admitida, deverá conter ou fazer-se acompanhar por este aviso.

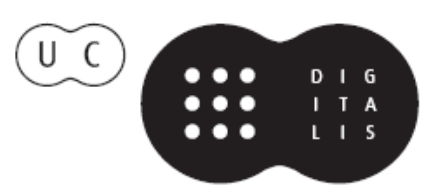




\section{Duarte Nuno Vieira Anthony Busuttil \\ Denis Cusack • Philip Beth}
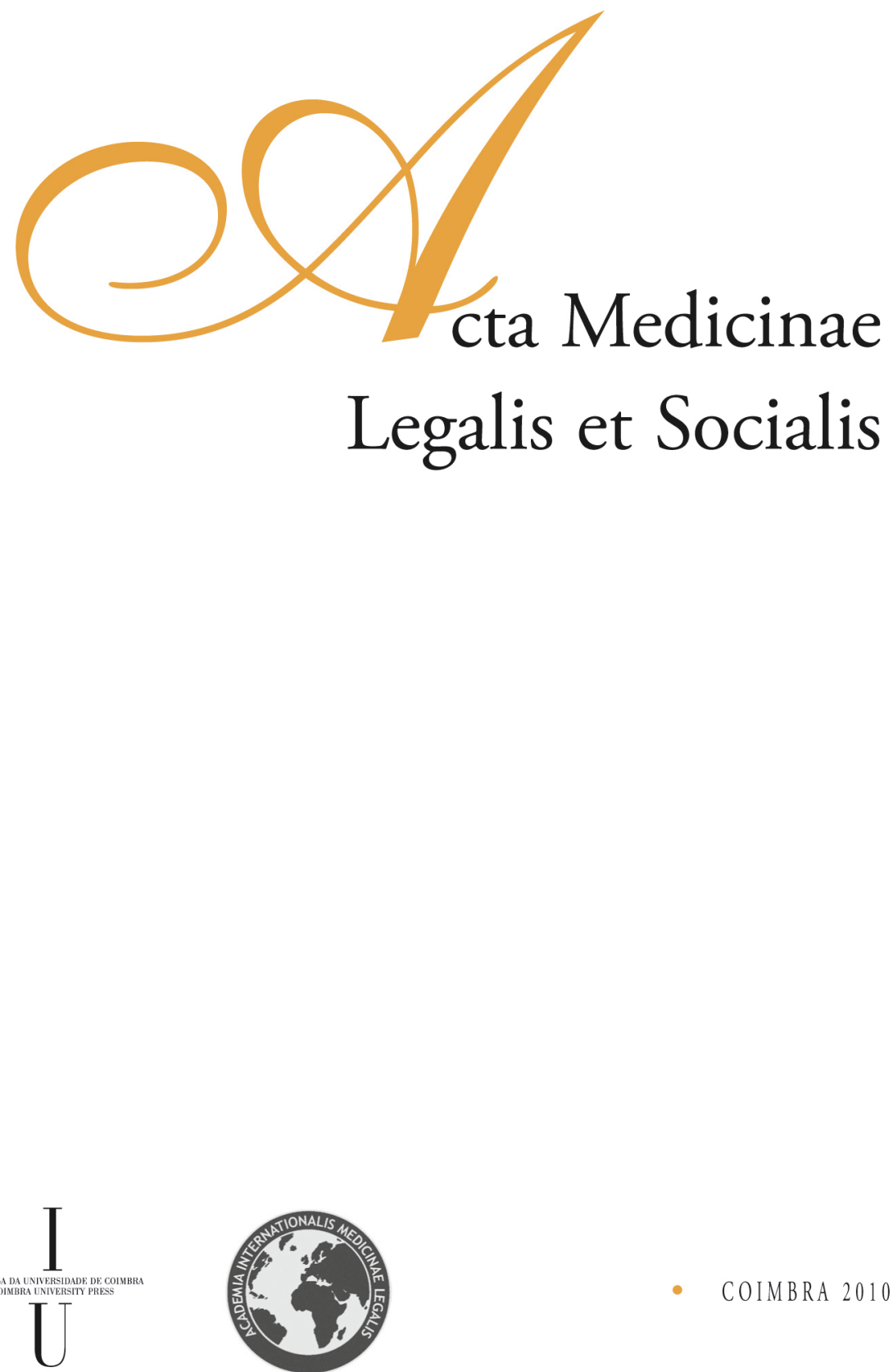
H. Afonso Costa ${ }^{1}$, F. Balsa ${ }^{1}$, A. M. Bento ${ }^{1}$, A. Serra ${ }^{1}$, V. Lopes ${ }^{1}$, M. Carvalho ${ }^{1}$, L. Andrade ${ }^{1}$, L. Batista ${ }^{1}$, C. Oliveira ${ }^{1}$, F. Corte-Real F. ${ }^{2,3}$, M. J. Anjos ${ }^{1}$

${ }^{1}$ Forensic Genetics Service, Centre Branch of the National Institute of Legal Medicine, Coimbra, Portugal

${ }^{2}$ National Institute of Legal Medicine, Coimbra, Portugal

${ }^{3}$ Faculty of Medicine, University of Coimbra, Portugal

\title{
SPECIES IDENTIFICATION FROM GENETIC MATERIAL WITH CYTOCHROME b
}

\begin{abstract}
Cytochrome b gene has a genetic content preserved between animals and it is used especially for the vertebrate's identification. In the forensic context it is specially used to determine the origin of non human samples. The sequencing strategy that was implemented in our laboratory, BigDey/BetterBuffer/XTerminator, allowed to reduce time procedures, improve quality of data and reduce significantly the cost per reaction comparing to other described methodologies. Using the program BLAST the obtained sequence is aligned and compared with sequences of the cytochrome b gene registered in a database (http://blast.ncbi.nlm.nih.gov/Blast.cgi). The aim of this study is the identification of several vertebrate animals to allow the resolution of eventual forensic cases in a shorter time than traditional methodologies and with lower costs.
\end{abstract}

\section{Introduction}

The nucleotide sequence of the cytochrome $\mathrm{b}(\mathrm{cytb})$ region of the mitochondrial DNA (mtDNA) holds specific information about diverse animal species. The analysis of the sequence of the cytb has been used in the identification of species in phylogenetic and forensic genetics fields. There are cases in the forensic context (traffic accidents involving animals, illegal traffic or hunter of animals, human attack perpetrated by animals, among others) in which identification of species is necessary for the case to be solved (Branicki et al., 2003).

The aim of this study is the identification of several vertebrate animals to allow the resolution of eventual forensic cases in a shorter time than traditional methodologies and with lower costs.

\section{Materials and Methods}

Blood samples were obtained from diverse mammals and birds. DNA was extracted using Chelex®100 method (Walsh et al., 1991). PCR amplification was performed with primers L14816 and H15173 (Parson et al., 2000) and chemistry of QIAGEN® Multiplex PCR Master Mix in a final volume of $25 \mu$ l. Thermocycling conditions 
were performed in a GeneAmp ${ }^{\circledR}$ PCR system 2700 (Applied Biosystems), followed the Parson et al., (2000) protocol. The cycle sequencing was performed using the ABI Prism ${ }^{\circledR}$ BigDye® Terminator v.1.1 Cycle Sequence Kit (Applied Biosystems); BetterBuffer (Microzone Limited, Sussek, UK) has been incorporated into the sequencing procedure. Before DNA analysis a simple bead purification method (XTerminator) was made, to remove the unincorporated BigDye terminators, unnecessary salts, and unused diluent buffer. The sequences were analysed in the sequencer 3130 - Genetic Analyser (ABI PRISM®) with the ABI DNA Sequencing Analysis Software v.5.2 and the SeqScape® Software v.2.5. Species were identified with BLAST 2.2.19+ (Smith et al., 1996, Zhang et al., 2000).

\section{Results}

Using the cytochrome b gene and Blast tool we were able to identify multiple species including Homo sapiens, Canis familiaris, Felis catus, Ovis aries and Turdus viscivorus. Figures 1, 2 and 3 show the steps that allow identifying samples species (in this case a bird sample).

\section{Discussion}

The sequencing strategy BigDye/BetterBuffer/XTerminator compared with others (for example dRhodamine/ ethanolic precipitation) allow to reduce time procedures, improve quality of data and reduce significantly the cost per reaction.

\section{Conclusions}

Results show that it is possible to identify multiple species with this low cost and faster methodology.

\section{References}

BRANICKI, W et al., Validation of cytochrome b sequence analysis as a method of species identification, J Forensic Sci 48, 1: 83-87, 2003.

PARSON, W et al., Species identification by means of the cytochrome b gene, Int Legal Med. 114(1-2): 23-8, 2000.

SMITH, R.F et al., BCM search launcher-an integrated interface to molecular biology data base search and analysis services available on the World Wide Web, Genome Res 6: 454-462, 1996.

WALSH, P.S et al., Chelex 100 as a medium for simple extraction of DNA for PCR-based typing for forensic casework analysis, Biotechniques 10,4: 506-513, 1991.

ZHANG, $Z$ et al., A greedy algorithm for aligning DNA sequences, J Comput Biol 7(1-2): 203-14, 2000. 




Figure 1 - Electropherogram sequence of Turdus viscivorus cytochrome b gene.

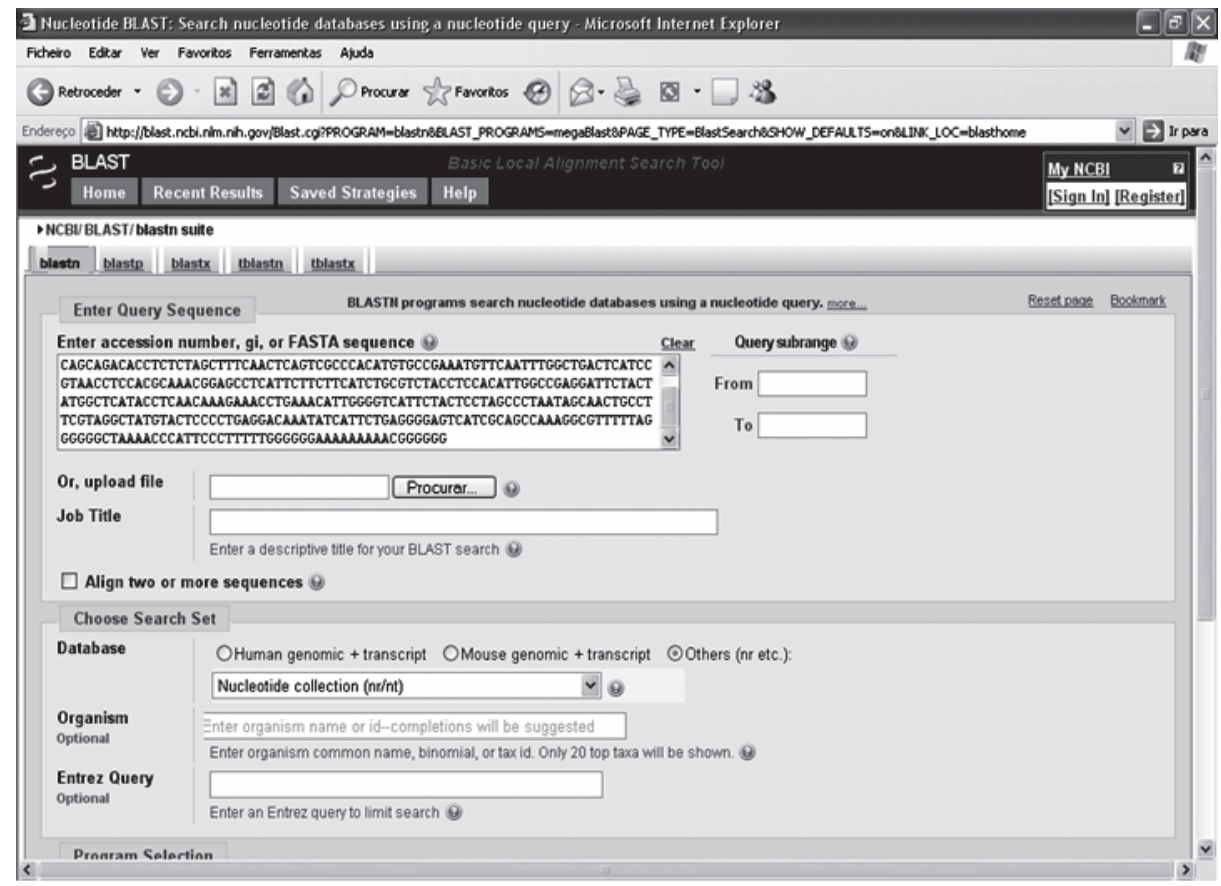

Figure 2 - Input on to Blast Web page of the nucleotide sequence as a query against all the public sequence databases [http://www.ncbi.nlm.nih.gov/BLAST/]. 


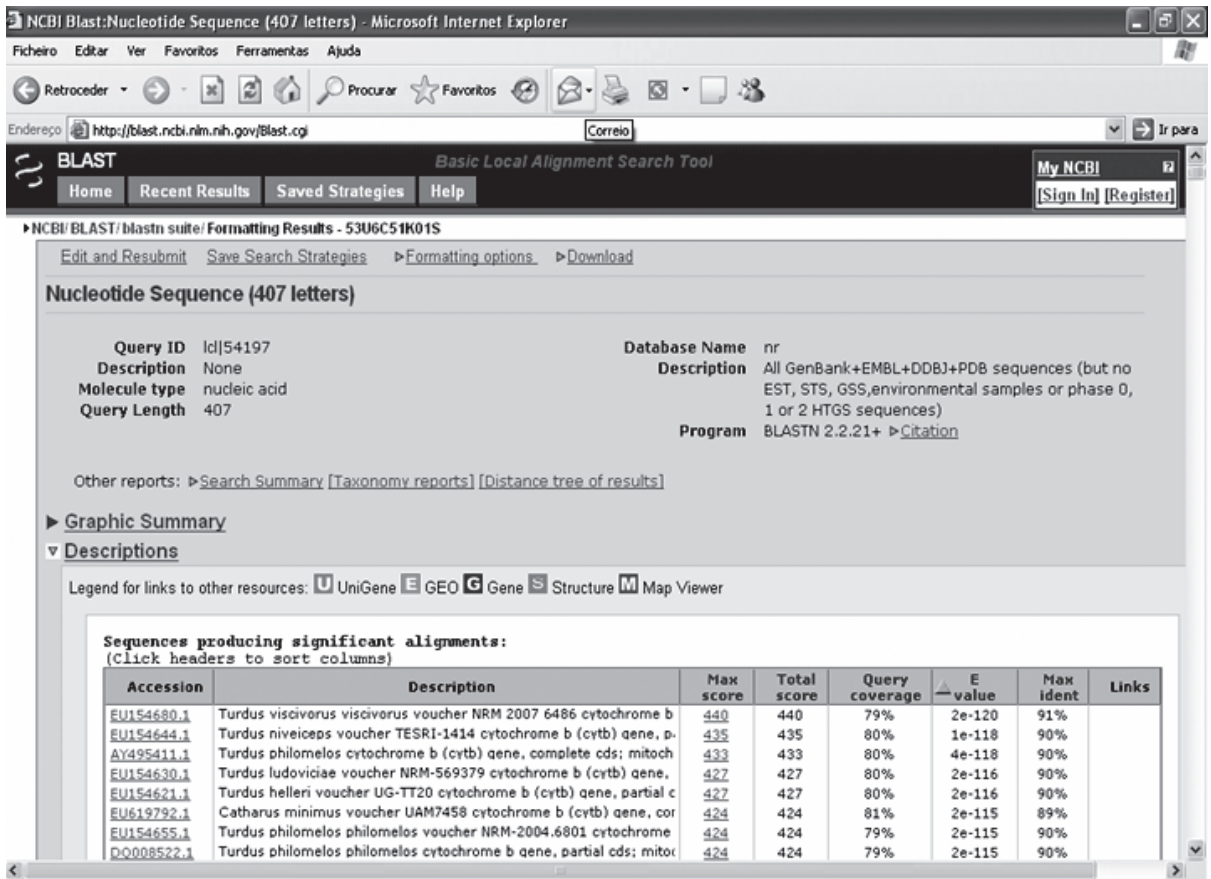

Figure 3 - Results of the search performed on the NCBI database and servers. 